\title{
Proposal of Claw Pole Type Double 2 Phase PM Stepping Motor
}

\author{
Akira Tozune Member (Ibaraki University, tozune@mx.ibaraki.ac.jp) \\ Toru TakeuchiＭember（Ibaraki University, takeuchi@mx.ibaraki.ac.jp) \\ Masafumi Sakamoto Member (Japan Servo Co., Ltd., msakamot@japanservo.co.jp)
}

Keywords: claw pole type, stepping motor, double two phase, alternating torque, cogging torque

Claw pole type 2 phase PM stepping motors (Fig. 1) are employed more than those of any other structur, because this type has simple structure and production cost is low. However, its performance is not necessarily satisfactory and a field of application is limited.

This paper is concerned with the improvement of performance of claw pole type 2 phase PM stepping motor. First, alternating torque and cogging torque of PM stepping motor are analyzed in relation to the harmonic components of winding currents and field flux, and the causes of generation of vibration torque and the frequency of these torque are clarified.

From the analytical results, the method of decreasing alternating torque and cogging torque is examined by using 2 sets of 2-phase PM motors (Fig. 2), that is, they are connected so that the generated variation torque on both motors may be canceled each other (this motor is called double 2 phase PM stepping motor (Fig. 3)).

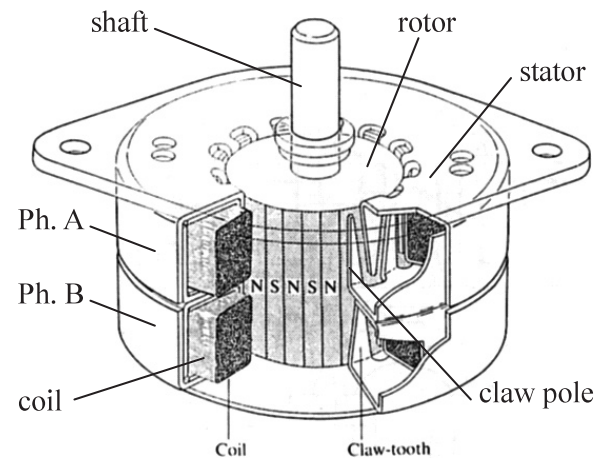

Fig. 1. Claw pole type 2 phase PM stepping motor

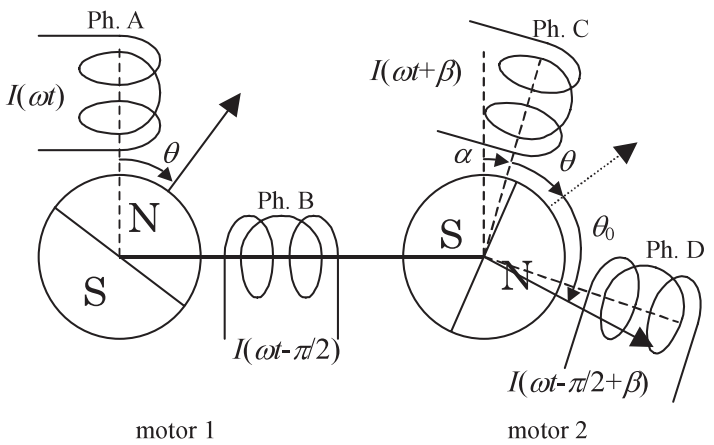

Fig. 2. Principal of reduction of torque variation
Characteristics of double 2-phase PM stepping motor are compared with those of 2-phase PM stepping motor. Fig. 4 is the comparison of speed variation. It is understood that the speed variation decreases greatly by use of a double 2 phase motor. Fig. 5 is the comparison of cogging torque. From this figure, it can be known that the cogging torque in double 2 phase motor is mainly present due to the existence of the 8th harmonic permiance component.

It becomes clear that the double 2 phase PM stepping motor not only brings half step angle, small alternating torque, small cogging torque but also improves step accuracy and pull-out torque characteristics.

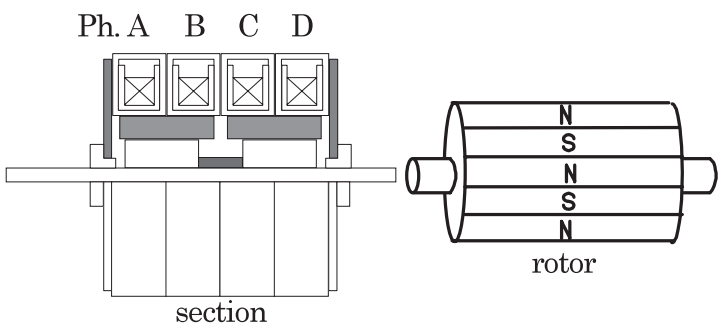

Fig. 3. Structure of double 2 phase PM stepping motor

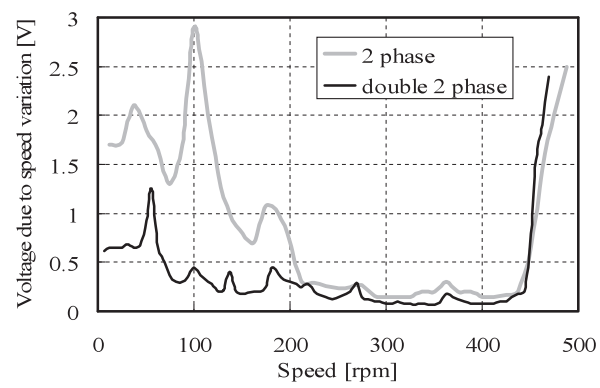

Fig. 4. Comparison of speed variation

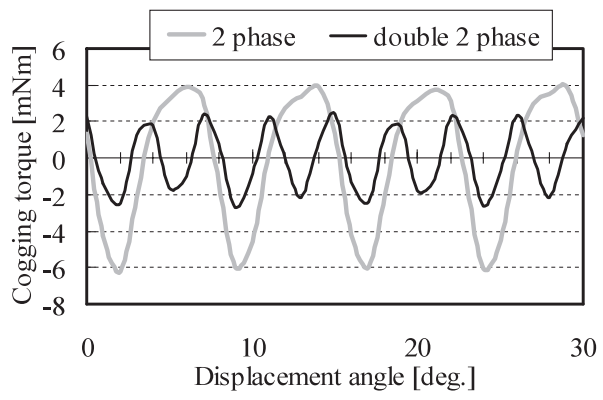

Fig. 5. Comparison of cogging torque 


\title{
クローポール形ダブル 2 相PMステッピングモータの提案
}

\author{
正員 戸恒 明* 正員竹内 亨* \\ 正 員 坂本 正文**
}

\section{Proposal of Claw Pole Type Double 2 Phase PM Stepping Motor}

\author{
Akira Tozune*, Member, Toru Takeuchi*, Member, Masafumi Sakamoto**, Member
}

This paper is concerned with the improvement of performance of claw pole type PM stepping motor. First, alternating torque and cogging torque of claw pole PM stepping motor are analyzed in relation to the harmonic components of winding currents and field flux, and the causes of generation of torque variation and their variation frequency are clarified.

Based on the above analytical results, the method for decreasing these torque variation is discussed, and the double 2 phase PM stepping motor is proposed, in which 2 sets of 2-phase PM motors are connected so that the generated variation torque of both motors may be canceled each other.

It becomes clear that the double 2 phase PM stepping motor not only brings small alternating torque and small cogging torque but also improves step accuracy and pull-out characteristics.

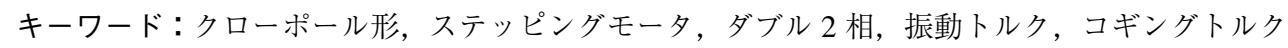

Keywords: claw pole type, stepping motor, double two phase, alternating torque, cogging torque

\section{1. はじめに}

ステッピングモータは開ループで制御ができることから， 事務機や自動化機器等に広く用いられている。近年, ステッ ピングモータにおいても, 高性能化の要望が高まるにつれ, HB 形ステッピングモータについては, 5 相機 (1) や 3 相機 (2)(3) の開発，また最近になって，3相機の分解能の向上と特性改 善を目指したダブル 3 相機の検討 ${ }^{(4)}$ など, 構造面からの検 討が多くなされてきた。一方, 構造が簡単で安価なクロー ポール形PM ステッピングモータにおいては，ステップ角 大，界磁磁束の高調波が大きいことに伴うコギングトルク $大^{(5)}$, ステップ角度誤差大, また連続回転時における振動卜 ルク大等の特性上の問題がある。しかし，その特性改善に 関しては，これまでに，界磁磁束の高調波の影響を電流の 高調波で打ち消すことで振動を低減しようとする試み(6) な どがなされているが，十分な効果は得られていないようで ある。したがって，クローポール形PM ステッピングモー

\footnotetext{
* 茨城大学工学部

干 316-8511 日立市中成沢町 4-12-1

Faculty of Engineering, Ibaraki University

4-12-1, Nakanarusawa, Hitachi 316-8511

** 日本サーボ (株)

干 376-0011 桐生市相生町 3-93

Japan Servo Co., Ltd.

3-93, Aioi, Kiryu 376-0011
}

夕については, 更なる特性の改善が求められる。

本論文では，2 相クローポール形 PM ステッピングモー 夕について，まず，一定回転時の特性や静特性に大きな影 響を及ぼす振動トルクおよびコギングトルクについて解析 し, それらと巻線電流および界磁磁束の高調波との関係, 並 びにそれらの変動周波数などを明らかにする。つぎに，振 動トルクおよびコギングトルクを低減させる方法として, これらの変動トルクと逆位相のトルクを, 別のもう一台の モー夕に発生させて互いに打ち消す方法（このような 2 台 のモータを一体化した構造をダブル 2 相モータと呼ぶこと にする）を考え (7)，そのための 2 台のモー夕の接続条件, 並 びに駆動条件について検討する。さらに，本方法による 2 相クローポール形 PM ステッピングモータの特性改善効果 を実験的に考察する。

\section{2 相機のトルク解析}

まず，回転時の特性および静特性に大きな影響を及ぼす 振動トルクとコギングトルクについて解析し, これらと電 流および界磁磁束の高調波との関連を明らかにする。

〈2・1〉振動トルクの解析 図 1 に示す 2 相クローポー ル形PM ステッピングモータは, 図 2 のような解析モデル で表される。

$\mathrm{A}$ 相, $\mathrm{B}$ 相の巻線電流 $I_{A}, I_{B}$ および回転子からの鎖交磁 束 $\phi_{A}, \phi_{B}$ をそれぞれ第 5 調波まで考慮して, 


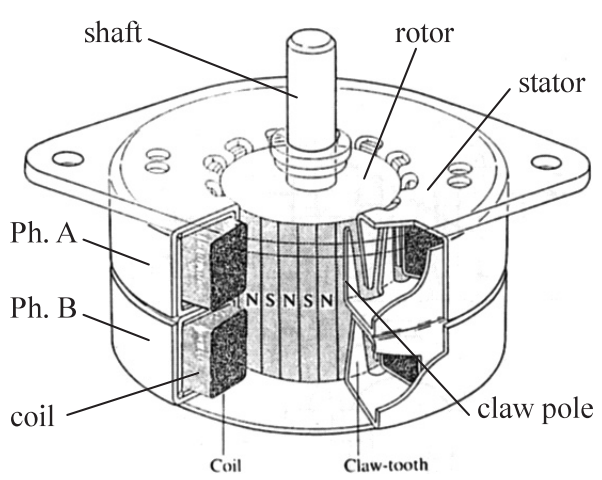

図 12 相クローポール形PM ステッピングモータ

Fig. 1. 2 phase claw pole type stepping motor.

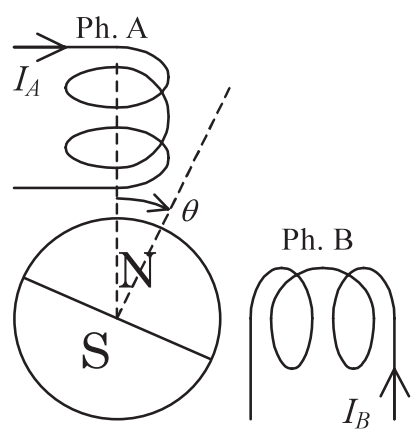

図 2 解析モデル

Fig. 2. Analytical model of 2 phase PM stepping motor.

$$
\left.\begin{array}{c}
I_{A}=I_{1} \cos \omega t+I_{3} \cos 3 \omega t+I_{5} \cos 5 \omega t \\
\phi_{A}=\phi_{1} \cos \theta+\phi_{3} \cos 3 \theta+\phi_{5} \cos 5 \theta \\
I_{B}=I_{1} \sin \omega t-I_{3} \sin 3 \omega t+I_{5} \sin 5 \omega t \\
\phi_{B}=\phi_{1} \sin \theta-\phi_{3} \sin 3 \theta+\phi_{5} \sin 5 \theta
\end{array}\right\} \ldots \ldots
$$

より求められ,

$$
\begin{aligned}
\tau_{1}= & I_{1} \phi_{1} \sin (\omega t-\theta)+3 I_{3} \phi_{3} \sin 3(\omega t-\theta) \\
& +5 I_{5} \phi_{5} \sin 5(\omega t-\theta) \\
& -3 I_{1} \phi_{3} \sin (\omega t+3 \theta)+5 I_{1} \phi_{5} \sin (\omega t-5 \theta) \\
& -I_{3} \phi_{1} \sin (3 \omega t+\theta)-5 I_{3} \phi_{5} \sin (3 \omega t+5 \theta) \\
& +I_{5} \phi_{1} \sin (5 \omega t-\theta)-3 I_{5} \phi_{3} \sin (5 \omega t+3 \theta)
\end{aligned}
$$

となる。ここで，負荷角を $\delta$ とし，一定速度で回転してい るものとして, $\theta=\omega t-\delta$ とおくと,

$$
\begin{aligned}
\tau_{1}= & I_{1} \phi_{1} \sin \delta+3 I_{3} \phi_{3} \sin 3 \delta+5 I_{5} \phi_{5} \sin 5 \delta \\
& -\left\{3 I_{1} \phi_{3} \sin (4 \omega t-3 \delta)+5 I_{1} \phi_{5} \sin (4 \omega t-5 \delta)\right. \\
& \left.+I_{3} \phi_{1} \sin (4 \omega t-\delta)-I_{5} \phi_{1} \sin (4 \omega t+\delta)\right\} \\
& -\left\{5 I_{3} \phi_{5} \sin (8 \omega t-5 \delta)+3 I_{5} \phi_{3} \sin (8 \omega t-3 \delta)\right\}
\end{aligned}
$$
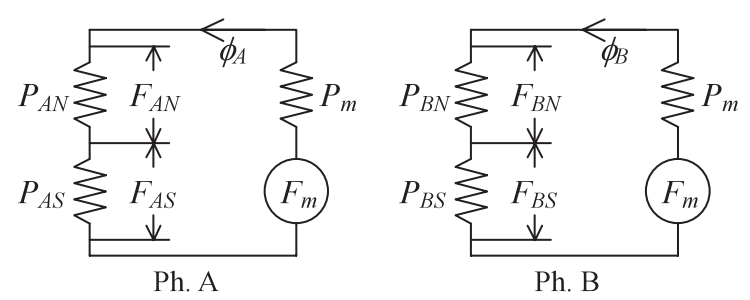

困 3 磁気等価回路

Fig. 3. Equivalent magnetic circuit.

となる。

(4) 式から，2 相励磁時における発生トルクは，一定トル クの他に電流周波数の 4 の整数倍調波の振動トルクが発生 することがわかる。また， 4 調波トルクは基本波電流と第 3 , 第 5 調波界磁磁束の作用, および基本波界磁磁束と第 3 , 第 5 調波電流の作用によって生じ，いずれも基本波成分 が関与することになるので，その值はかなり大きくなるも のと思われる。一方，8調波より高次の振動卜ルクは高次 の電流と高次の界磁磁束の作用によって生じ, 基本波成分 はかかわっていないため, それらはあまり大きな值にはな らないことがわかる。

〈2・2〉 コギングトルクの解析 A 相のクローポール がそれぞれ回転子の $\mathrm{N}$ 極と $\mathrm{S}$ 極に正対向しているとき, $\mathrm{B}$ 相のクローポールは $\mathrm{N}$ 極および $\mathrm{S}$ 極とそれぞれ $\pi / 2$ ずれて 対向することになる。したがって, A 相のギャップパーミ アンス $P_{A N}, P_{A S}$ および $\mathrm{B}$ 相のギャップパーミアンス $P_{B N}$, $P_{B S}$ はそれぞれ (5) 式のような関係で表される。1 相分の マグネットのパーミアンスと起磁力をそれぞれ $P_{m}, F_{m}$ と 表すと, 各相の磁気回路は互いに独立していることから磁 気等価回路は図 3 のように表される。このことから, 各相 の奇数次ギャップパーミアンスは現れないことになる。

$$
\left.\begin{array}{rl}
P_{A N}= & P(\theta)=P_{0}+P_{1} \cos \theta+P_{2} \cos 2 \theta \\
& +P_{3} \cos 3 \theta+P_{4} \cos 4 \theta+\cdots \\
P_{A S}= & P(\theta-\pi) \\
P_{B N}= & P(\theta-\pi / 2) \\
P_{B S}= & P(\theta-3 \pi / 2)
\end{array}\right\}
$$

図 3 から A 相のギャップ磁気エネルギー $W_{m A}$ は

$$
W_{m A}=\frac{1}{2} F_{A N}^{2} P_{A N}+\frac{1}{2} F_{A S}^{2} P_{A S}
$$

と表される。ここで $P_{0} \gg P_{m}, P_{0} \gg P_{n}(n=1,2,3,4, \cdots)$ の関係を用いると,

$$
\left.\begin{array}{l}
F_{A N}=F_{m} \frac{1 / P_{A N}}{1 / P_{m}+1 / P_{A N}+1 / P_{A S}} \cong \frac{P_{m}}{P_{0}} F_{m} \\
F_{A S}=F_{m} \frac{1 / P_{A S}}{1 / P_{m}+1 / P_{A N}+1 / P_{A S}} \cong \frac{P_{m}}{P_{0}} F_{m}
\end{array}\right\}
$$

となり， 


$$
\begin{aligned}
\therefore \quad W_{m A} & =\frac{1}{2}\left(\frac{P_{m}}{P_{0}}\right)^{2} F_{m}^{2}\left(P_{A N}+P_{A S}\right) \\
& =\left(\frac{P_{m}}{P_{0}}\right)^{2} F_{m}^{2}\left(P_{0}+P_{2} \cos 2 \theta+P_{4} \cos 4 \theta+\cdots\right)
\end{aligned}
$$

となる。したがって，A 相のコギングトルク $\tau_{g A}$ は回転子 の磁極対数を $N_{R}$ とすると, $\theta=N_{R} \theta_{m}$ の関係から

$$
\begin{aligned}
\tau_{g A} & =-\frac{\partial W_{m A}}{\partial \theta_{m}} \\
& =2 N_{R}\left(\frac{P_{m}}{P_{0}}\right)^{2} F_{m}^{2}\left(P_{2} \sin 2 \theta+2 P_{4} \sin 4 \theta+\cdots\right)
\end{aligned}
$$

となる。同様にして, B 相のコギングトルク $\tau_{g B}$ は,

$$
\begin{aligned}
\tau_{g B}= & 2 N_{R}\left(\frac{P_{m}}{P_{0}}\right)^{2} F_{m}^{2}\left\{P_{2} \sin 2\left(\theta+\frac{\pi}{2}\right)\right. \\
& \left.+2 P_{4} \sin 4\left(\theta+\frac{\pi}{2}\right)+\cdots\right\} \cdots \cdots
\end{aligned}
$$

となるから， A， B 相の合成コギングトルク $\tau_{g 1}$ は

$$
\begin{aligned}
\tau_{g 1} & =\tau_{g A}+\tau_{g B} \\
& =8 N_{R}\left(\frac{P_{m}}{P_{0}}\right)^{2} F_{m}^{2}\left(P_{4} \sin 4 \theta+P_{8} \sin 8 \theta+\cdots\right)
\end{aligned}
$$

となり, 界磁磁束の 4 の整数倍調波のコギングトルクを発 生することがわかる。

\section{3. ダブル 2 相機の提案}

〈3・1〉 トルク変動低減の原理（4) 式からわかるよう に，4 調波振動トルクの合成值は負荷状態，すなわち， $\delta$ に よって変化することになるため, 全ての使用状況において 振動トルクを低減することは容易ではないように思われる。

そこでここでは, いかなる使用状態においても, 発生す る振動トルクとコギングトルクが，常にこれらと逆位相の トルクを発生するもう 1 台のモータによって同時に打ち消 され，全体として変動トルクが低減するような方法を検討 する(図 4, 図 5 参照)。

〈3.2〉 ダブル 2 相機のトルク解析 図 6 に示すよう に，2台の 2 相 PM モー夕を直結することを考える。その 際，同図に示すように，2 組の 2 相機は，A 相巻線軸と回 転子磁極の位置関係および $\mathrm{C}$ 相巻線軸と回転子磁極の位置 関係が電気角で $\theta_{0}$ だけずれるようにして直結し，さらに第 2 モータに流れる電流の位相を第 1 モー夕の電流よりそれ ぞれ $\beta$ だけ進めるようにする。このとき発生する振動卜ル クおよびコギングトルクについて検討する。

$\langle\mathbf{3 \cdot 2 \cdot 1 \rangle}$ 振動トルク 図6の C 相と D 相によって発 生するトルク $\tau_{2}$ を, $\mathrm{A}, \mathrm{B}$ 相のときと同様にして求める。

いま, $\mathrm{C}$ 相, $\mathrm{D}$ 相の巻線電流 $I_{C}, I_{D}$ および $\mathrm{C}$ 相, $\mathrm{D}$ 相 の回転子からの鎖交磁束 $\phi_{C}, \phi_{D}$ をそれぞれ第 5 調波まで

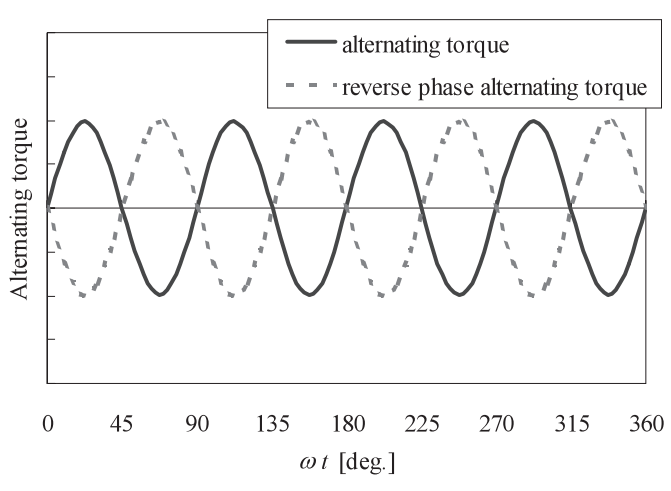

図 4 振動低減の原理

Fig. 4. Principle of alternating torque reduction.

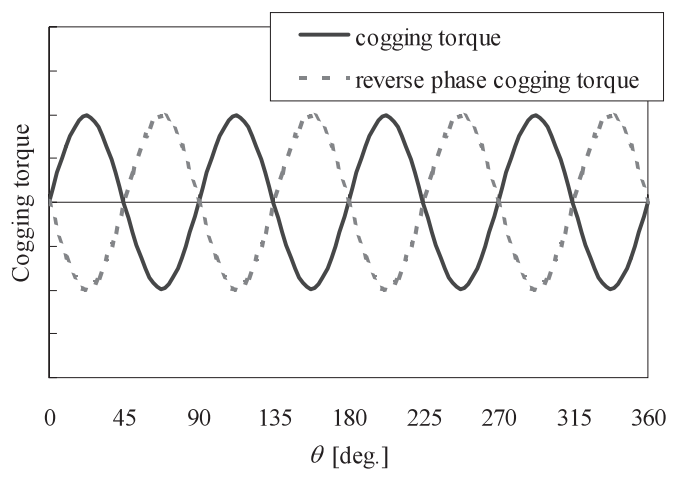

図 5 コギングトルク低減の原理

Fig. 5. Principle of cogging torque reduction.

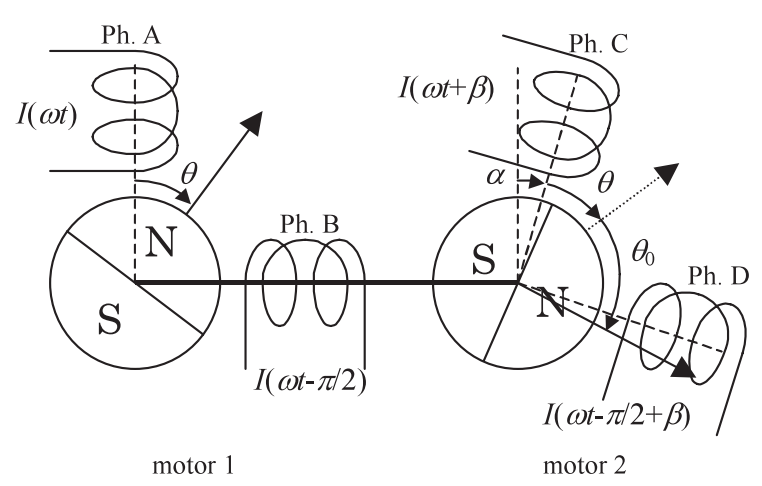

図 6 ダブル 2 相機解析モデル

Fig. 6. Analytical model of double 2 phase PM stepping motor.

考慮して，

$$
\left.\begin{array}{l}
I_{C}=I_{1} \cos (\omega t+\beta)+I_{3} \cos 3(\omega t+\beta)+I_{5} \cos 5(\omega t+\beta) \\
\phi_{C}=\phi_{1} \cos \left(\theta+\theta_{0}\right)+\phi_{3} \cos 3\left(\theta+\theta_{0}\right)+\phi_{5} \cos 5\left(\theta+\theta_{0}\right) \\
I_{D}=I_{1} \sin (\omega t+\beta)-I_{3} \sin 3(\omega t+\beta)+I_{5} \sin 5(\omega t+\beta) \\
\phi_{D}=\phi 1 \sin \left(\theta+\theta_{0}\right)-\phi_{3} \sin 3\left(\theta+\theta_{0}\right)+\phi_{5} \sin 5\left(\theta+\theta_{0}\right)
\end{array}\right\}
$$

とおき,さらに $\theta=\omega t-\delta$ として一定回転時のトルクを求 めると, 


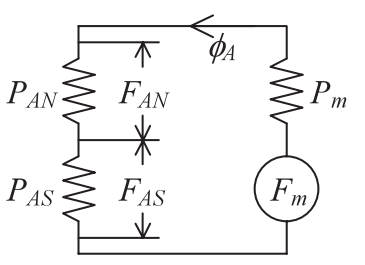

$\mathrm{Ph} . \mathrm{A}$

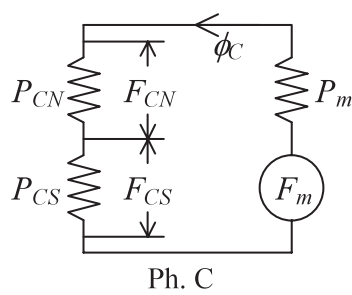

図 7 ダブル 2 相機磁気等価回路

Fig. 7. Equivalent magnetic circuit of double 2 phase PM stepping motor.

$$
\begin{aligned}
\tau_{2}= & I_{1} \phi_{1} \sin \left(\delta+\beta-\theta_{0}\right)+3 I_{3} \phi_{3} \sin 3\left(\delta+\beta-\theta_{0}\right) \\
& +5 I_{5} \phi_{5} \sin 5\left(\delta+\beta-\theta_{0}\right) \\
& -3 I_{1} \phi_{3} \sin \left(4 \omega t-3 \delta+\beta+3 \theta_{0}\right) \\
& -5 I_{1} \phi_{5} \sin \left(4 \omega t-5 \delta-\beta+5 \theta_{0}\right) \\
& -I_{3} \phi_{1} \sin \left(4 \omega t-\delta+3 \beta+\theta_{0}\right) \\
& -5 I_{3} \phi_{5} \sin \left(8 \omega t-5 \delta+3 \beta+5 \theta_{0}\right) \\
& +I_{5} \phi_{1} \sin \left(4 \omega t+\delta+5 \beta-\theta_{0}\right) \\
& -3 I_{5} \phi_{3} \sin \left(8 \omega t-3 \delta+5 \beta+3 \theta_{0}\right) \cdots \cdots \cdots(
\end{aligned}
$$

となる。

(4) 式と (13) 式を比較すると, モー夕 1 の 4 調波振動卜 ルクがモータ 2 によって打ち消されるためには，以下のよ うな関係を持たせることが必要であることがわかる。

$$
\beta=\theta_{0}=\pi / 4
$$

このとき, モータ 1 , モータ 2 が発生する全トルク $\tau$ は (15) 式のようになる。

$$
\begin{aligned}
\tau= & 2\left\{I_{1} \phi_{1} \sin \delta+3 I_{3} \phi_{3} \sin 3 \delta+5 I_{5} \phi_{5} \sin 5 \delta\right\} \\
& -2\left\{5 I_{3} \phi_{5} \sin (8 \omega t-5 \delta)+3 I_{5} \phi_{3} \sin (8 \omega t-3 \delta)\right\}
\end{aligned}
$$

(15) 式から，(14) 式を満たすように2 台の 2 相機を直結 した場合（これをダブル 2 相機と呼ぶことにする）には， 第 4 調波振動卜ルクは負荷に関係なく消去されていること がわかる。

〈3·2·2〉 コギングトルク 図 6 の無励磁における磁 気等価回路は, $P_{C N}, P_{C S}$ を $\mathrm{C}$ 相の $P_{D N}, P_{D S}$ を D 相の ギャップパーミアンスとすると, 図 7 のように表される。 ギャップパーミアンス $P_{C N}, P_{C S}, P_{D N}, P_{D S}$ は (14) 式の 関係が成り立っているときには，次式のように表される。

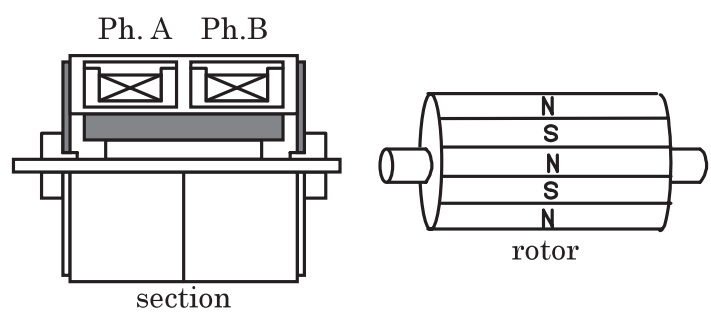

(a) 2 phase PM stepping motor.

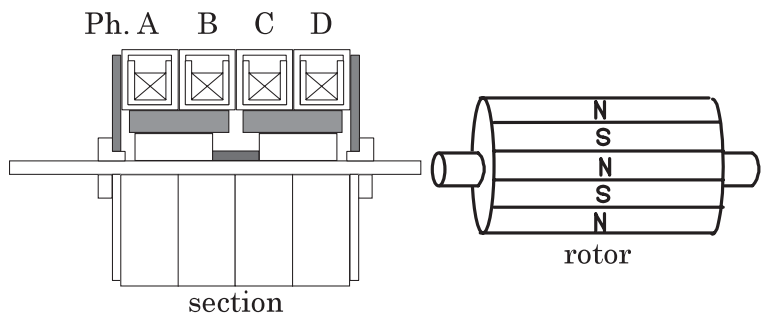

(b) Double 2 phase PM stepping motor.

図 8 モー夕構造図

Fig. 8. Structures of 2 phase and double 2 phase PM stepping motor.

$$
\left.\begin{array}{l}
P_{C N}=P(\theta-\pi / 4) \\
P_{C S}=P(\theta-5 \pi / 4) \\
P_{D N}=P(\theta-3 \pi / 4) \\
P_{D S}=P(\theta-7 \pi / 4)
\end{array}\right\}
$$

このとき, $\mathrm{C}, \mathrm{D}$ 相のコギングトルク $\tau_{g 2}$ を $\mathrm{A}, \mathrm{B}$ 相のとき と同様にして求めると,

$$
\begin{aligned}
\tau_{g 2}= & 8 N_{R}\left(\frac{P_{m}}{P_{0}}\right)^{2} F_{m}^{2}\left\{P_{4} \sin 4\left(\theta+\frac{\pi}{2}\right)\right. \\
& \left.+P_{8} \sin 8\left(\theta+\frac{\pi}{2}\right)+\cdots\right\} \cdots \cdots
\end{aligned}
$$

となる。 $\mathrm{A} ， \mathrm{~B}$ 相と合わせた全体のコギングトルク $\tau_{g}$ は

$$
\begin{aligned}
\tau_{g} & =\tau_{g 1}+\tau_{g 2} \\
& =16 N_{R}\left(\frac{P_{m}}{P_{0}}\right)^{2} F_{m}^{2}\left(P_{8} \sin 8 \theta+\cdots\right)
\end{aligned}
$$

となり，4調波のコギングトルクは除去されていることが わかる。これは, モータ 1 の $\mathrm{A}$ 相巻線軸とモータ 2 の $\mathrm{C}$ 相 巻線軸では回転子磁軸とのなす角が $\pi / 4$ ずれていることか ら, 両モータの発生する 4 調波のコギングトルクは逆位相 となり互いに打ち消されるためである。

したがって, 図 6 に示す 2 台のモータを (14) 式の条件を 満たすダブル 2 相機にすれば, 振動トルク, コギングトル クとも低減されることになる。

$\langle\mathbf{3} \cdot \mathbf{3}\rangle$ ダブル 2 相機構造上記の結果から, 全発生 トルクは，図 6 中の $\alpha$ には無関係，すなわち，2台のモー 夕の固定子巻線軸の位置関係には影響されないことになる から $\alpha$ を $\pi / 4$ に固定し, 2 台のモータの回転子磁軸を一 致させた方が 1 個の回転子を共通に使用でき, 製作上有利 であると思われる。そこで, 図 8(b) に示すように, 固定子 を 4 相構造として A, B, C, D 相の固定子歯の配置を順に 


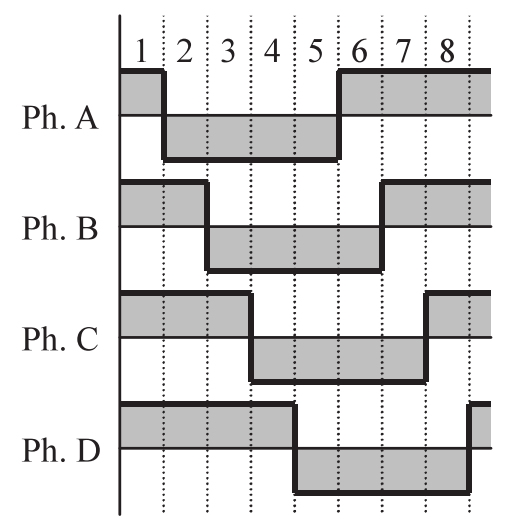

図 9 電流波形

Fig. 9. Current waveforms.

$\pi / 4$ (電気角) ずらした構造にすればよいことになる。な お，このときの各相電流波形は図 9 のようになる。この夕゙ ブル 2 相機構造により, 振動トルク, コギングトルクの小 さいクローポール形PM ステッピングモータが得られるこ とになる。

\section{4. 実測結果}

$\langle\mathbf{4} \cdot \mathbf{1}\rangle$ 実験方法 実験は便宜上, 同一の 2 相 PM モー 夕（仕様を表 1 に示す） 2 台を用いて行った。まず， 2 台 のモー夕を直結し，これを外力で一定速度にて回転させる。 このときに，A 相と $\mathrm{C}$ 相に誘起する電圧の位相が同相にな るように回転子を直結した場合を通常の 2 相モー夕（2 台 並列運転）と考え，また， $\mathrm{A}$ 相と $\mathrm{C}$ 相に誘起する電圧の位 相差が電気角で $\pi / 4$ となるように直結された場合をダブル 2 相機として扱った。なお，各相に流した電流波形を図 9 に示す。図 9 からステップ角は 2 相機の $1 / 2$ となることが わかる。

〈4·2〉 特性比較 図 10 にフルステップ駆動時, 図 11 にマイクロステップ駆動時（8 分割）の速度変動の比較を 示す。両者とも, 特に低速領域に扔いて速度変動が大幅に 改善されていることがわかる。これは，4 調波の振動卜ル クが減少したことにより，共振が抑えられたためと考えら れる。な损，速度変動はステッピングモー夕に低慣性のコ アレスモータを直結させ，その出力電圧から測定した。

つぎに，コギングトルクの比較を図 12 に示した。比較 するに当たって，まず 2 相機 1 台のコギングトルクを測定 し，これを 2 倍したものと， 2 相機 1 台のコギングトルク の測定結果に，これと位相を $\pi / 4$ ずらせたトルクを加えた ものをダブル 2 相機のコギングトルクとし，両者を比較し た。図 12 には，ダブル 2 相機にすることによって, (18) 式 から予想されるように，4 調波コギングトルクは打ち消さ れ，コギングトルクは主に 8 調波成分となり，その值は 2 相機 4 調波コギングトルクの $40 \%$ 程度となることが示され ている。

つぎに， 2 相機およびダブル 2 相機のステップ誤差を測
表 1 供試機の仕様

Table 1. Specifications of sampled motor.

\begin{tabular}{|l|l|}
\hline Number of pole & 24 \\
\hline Winding resistance & $12[\Omega /$ phase $]$ \\
\hline Winding inductance & $6.1[\mathrm{mH} / \mathrm{phase}]$ \\
\hline Step angle & $7.5[\mathrm{deg}]$. \\
\hline Stator outer diameter & $49[\mathrm{~mm}]$ \\
\hline Stack length & $21.8[\mathrm{~mm}]$ \\
\hline
\end{tabular}

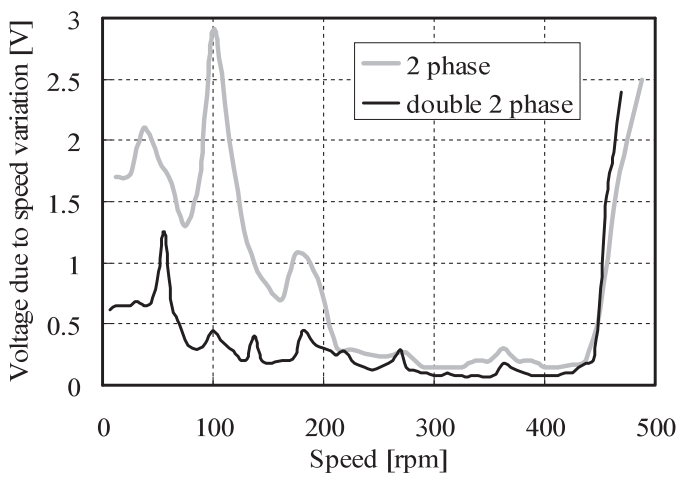

図 10 回転むら特性の比較（フルステップ駆動）

Fig. 10. Comparison of speed variation (full step operation).

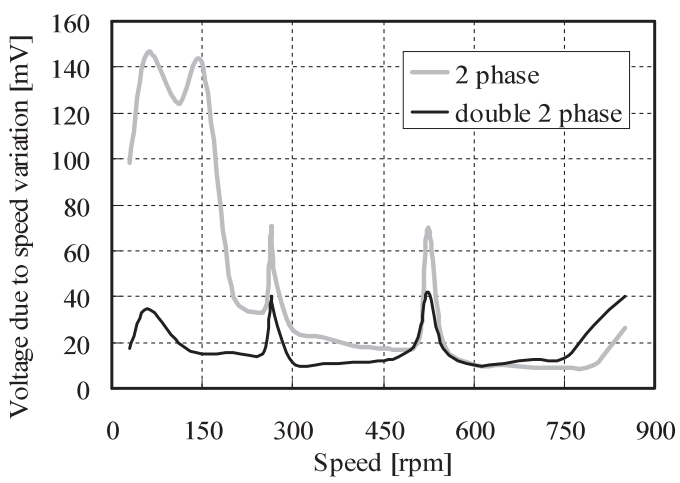

図 11 回転むら特性の比較（マイクロステップ駆動）

Fig. 11. Comparison of speed variation (micro step operation).

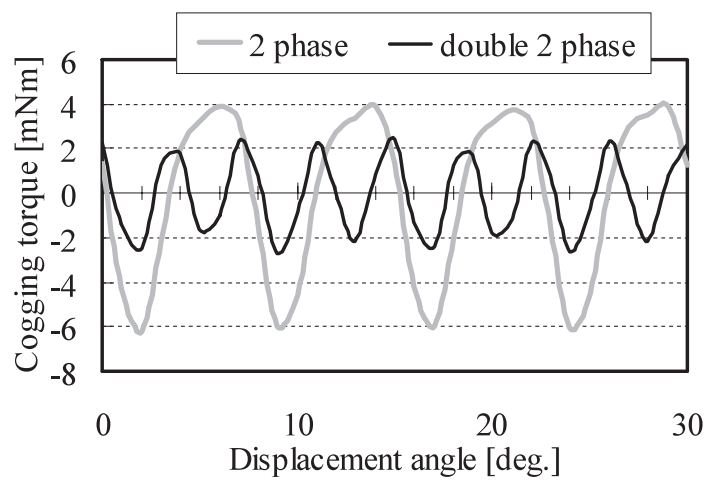

図 12 コギングトルクの比較

Fig. 12. Comparison of cogging torque. 


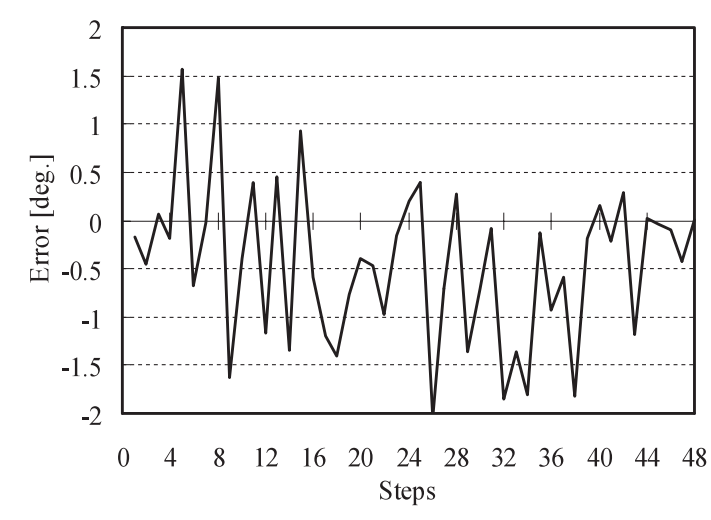

困 132 相機ステップ誤差

Fig. 13. Step position error (2 phase motor).

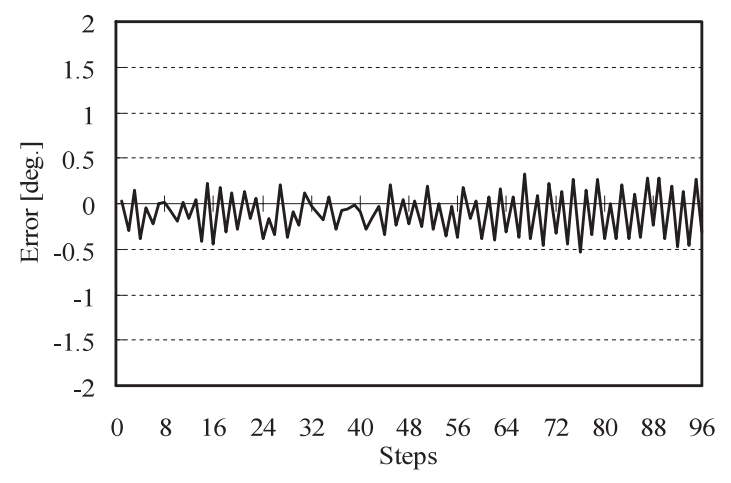

図 14 ダブル 2 相機ステップ誤差

Fig. 14. Step position error (double 2 phase motor).

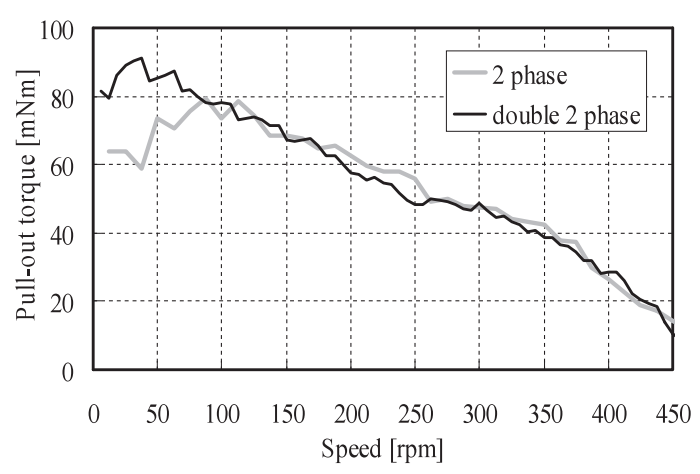

図 15 脱出トルク特性

Fig. 15. Characteristics of pull-out torque.

定した結果をそれぞれ，図 13，図 14 に示す。同図から，2 相機はステップ角度誤差が $2^{\circ}$ 程度 (ステップ角 $7.5^{\circ}$ ) ある のに対し，ダブル 2 相機は $0.45^{\circ}$ 程度（ステップ角 $3.75^{\circ}$ ) にとどまっており，ステップ誤差特性も大幅に改善される ことがわかる。

図 15 に脱出トルク特性の比較を示す。同図に見られる ように，低速域でのトルクが改善されているが，これは振 動トルクの減少に伴い共振の影響が軽減したものと考えら れる。

\section{5. まとめ}

2 相クローポール形 PM ステッピングモータの特性改善 について検討し，以下のことを得た。

（1）電流および界磁磁束に高調波を含む場合の振動卜 ルクおよびコギングトルクの表示式を誘導し，これ らの発生原因，これらのトルクと各高調波次数との 関係，変動トルクの周波数などを明らかにした。

（2）振動トルクおよびコギングトルクを，2 組の 2 相 PM 形ステッピングモータを用い，それぞれのモー 夕に逆位相の変動トルクを発生させて全体として変 動トルクを低減させる方法を提案し，そのための条 件を求めた（ダブル 2 相 PM ステッピングモータの 提案)。

（3）ダブル 2 相機と従来の 2 相機との特性比較を行っ た。その結果，ステップ角が $1 / 2$ となると同時に，振 動トルク，コギングトルクが大幅に減少すること，ま た，脱出トルク特性の低速領域における特性が改善 されること, ステップ誤差が大幅に小さくなること など，ダブル 2 相機の適用により，クローポール形 PM ステッピングモータの特性が特性全般に亘って 改善されることが明らかになった。

以上のことから, クローポール形 PM ステッピングモー 夕の応用範囲が一層広がることが期待される。

(平成 18 年 7 月 11 日受付，平成 18 年 11 月 22 日再受付)

$$
\text { 文献 }
$$

(1) H. Domeki: "Characteristics comparison among polyphase stepping motors", RM-93, No.22-31, pp.9-16 (1993) (in Japanese)

百目鬼英雄：「多相ステッピングモータの特性比較」, 電学回転機研 資, RM-93, No.22-31, pp.9-16 (1993)

(2) K. Ohnishi, M. Sakamoto, K. Isozaki, N. Sasaki, and Y. Kuwano: "Development of Three -Phase HB-type Stepping Motors", T. IEE Japan, Vol.116-D, No.6, pp.578-583 (1996-6) (in Japanese)

大西和夫 ·坂本正文 - 磯崎弘馗 ·佐々木直孝 ·桑野好文 : 「3 相 HB 形ステッピングモータの開発」, 電学論 D, 116, 6, pp.578-583 (1996-6)

(3) A. Tozune, M. Sakamoto, M. Iida, and T. Horii: "Characteristics of Hybrid Type 3-Phase Stepping Motor", T. IEE Japan, Vol.117-D, No.6, pp.743-750 (1997-6) (in Japanese)

戸恒 明・坂本正文・飯田真之・堀井龍夫：「3 相ハイブリッド形ス テッピングモータの基礎特性」, 電学論 D, 117, 6, pp.743-750 (1997-6)

(4) M. Sakamoto and A. Tozune: "Study of Double 3 Phase Hybrid Type Stepping Motor", T. IEE Japan, Vol.117-D, No.3, pp.393-394 (1997-3) (in Japanese)

坂本正文・戸恒 明:「ダブル 3 相ハイブリッド形ステッピングモー 夕の検討」, 電学論 D, 117, 3, pp.393-394 (1997-3)

(5) Y. Kawase, T. Yamaguchi, Y. Mizuno, and Y. Koike: "3-D Finite Element Analysis of Cogging Torque Characteristics of Claw-Poled Stepping Motor", The 2000 Annual Meeting Record of IEE Japan, No.5-019 (2000) (in Japanese)

河瀬順洋・山口 忠·水野泰成 - 小池良和：「三次元有限要素法を 用いたクローポール形ステッピングモータのコギングトルク特性解 析」, 平 12 年電学全大講演論文集, No.5-019 (2000)

（6）百目鬼英雄：「ハイブリッド PM ステッピングモータのマイクロス テップの検討」, 電学回転機研資, RM-88, No.93, pp.9-16 (1988)

( 7 ) H. Kato, A. Tozune, T. Takeuchi, and M. Sakamoto: "Characteristics of Double 2 Phase Claw Pole Type Stepping Motor", The 2006 Annual Meeting Record of IEE Japan, No.5-094 (2006) (in Japanese)

加藤栄光・戸恒 明・竹内 亨・坂本正文：「ダブル 2 相クローポー ル形ステッピングモータの特性検討」, 平 18 年電学全大講演論文集, No.5-094 (2006) 


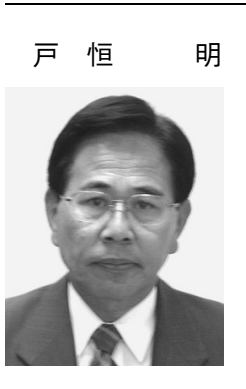

明（正員） 1941 年 7 月 16 日生。1967 年 3 月群馬 大学大学院修士課程電気工学専攻修了。同年 4 月 三洋電機 (株) 入社。1970 年 1 月群馬大学工学 部助手。講師, 助教授を経て 1992 年 4 月茨城大 学工学部教授, 現在に至る。主として, 制御機器 に関する研究に従事。工学博士。計測自動制御学 会, システム制御情報学会, IEEE 会員。

坂 本 正 文 (正員) 1941 年 7 月 15 日生。1965 年 3 月群馬

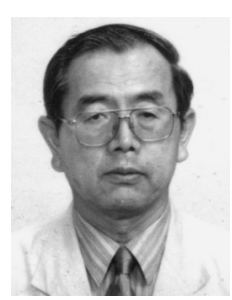
大学工学部電気工学科卒業。同年 4 月, 日本サ一 ボ (株) 入社。桐生工場にてシンクロナスモー夕, ステッピングモータの設計, 開発に従事。技師長。 工学博士。

竹 内 亨 (正員) 1971 年 10 月 14 日生。1999 年 3 月茨城 大学大学院理工学研究科博士後期課程生産科学専 攻満期退学。同年 4 月茨城大学工学部助手, 現在 に至る。主として，メカトロニクスの制御に関す る研究に従事。博士 (工学)。精密工学会会員。 